\title{
Effects of skills, motivation, and personality traits on the competency of masons
}

\author{
Rafiq Muhammad Choudhry* \\ Department of Civil and Environmental Engineering, \\ College of Engineering, \\ King Faisal University, \\ Al-Ahsa-31982, Saudi Arabia \\ Fax: +96635817068 \\ Email: rchoudhry@kfu.edu.sa \\ *Corresponding author
}

\section{Bilal Zafar}

Department of Construction Engineering and Management, School of Civil and Environmental Engineering,

National University of Sciences and Technology,

Islamabad, Pakistan

Email: bz4121986@yahoo.com

\begin{abstract}
Incompetency of masons is a problem because they execute many construction activities. This imparts the need to identify factors that affect the competency of masons on construction sites. Factors related to motivation, skills and personality traits are identified. A questionnaire instrument consisting of 15 factors related to the three categories was forwarded to masons on construction projects. Responses collected on a five-point Likert scale were analysed for relative importance index (RII), which was used as the basis for ranking the factors. 'Resistance to change', 'lack of appreciation', and 'lack of formal training' were identified as the first, second, and third most important factors affecting the competency of masons on construction projects. The impact of the category of motivation was found to be the highest on the competency of masons, followed by skills, and personality traits. These findings may be utilised as an assessment tool for determining the competency of masons and identifying areas that need improvements.
\end{abstract}

Keywords: masons; competency; performance; skills; motivation; personality traits.

Reference to this paper should be made as follows: Choudhry, R.M. and Zafar, B. (2017) 'Effects of skills, motivation, and personality traits on the competency of masons', Int. J. Sustainable Real Estate and Construction Economics, Vol. 1, No. 1, pp.16-30.

Biographical notes: Rafiq Muhammad Choudhry has over 25 years of construction industry research and teaching experience. He is a Professor of Construction Engineering and Management, Department of Civil and Environmental Engineering, King Faisal University, Saudi Arabia. Before joining the academic environment, he served nine years in the construction industry and completed three large projects. He organised a number of conferences and seminars. His experience in industry and subsequent research 


\begin{abstract}
has demonstrated a strong interest in improving the efficiency, productivity and safety of construction projects. He has published 81 papers in refereed journals and conferences.
\end{abstract}

Bilal Zafar is a graduate student in the Department of Construction Engineering and Management at the School of Civil and Environmental Engineering, National University of Sciences and Technology, Islamabad, Pakistan.

This paper is a revised and expanded version of a paper entitled 'Factors affecting competency of masons in construction' presented at Creative Construction Conference, Budapest, Hungary, 30 June to 3 July 2012.

\title{
1 Introduction
}

Cost overrun in construction projects is a problem commonly observed in both developing and developed countries (Memon et al., 2014). One way in which cost overrun can be controlled is by maximising the competency of masons as they perform the bulk of construction work. Competency includes knowledge or skill as well as other characteristics such as levels of motivation and personality traits (Dubois et al., 2004). Skill, motivation, and personality traits are inferred as the categories comprising factors that affect competency.

Construction work is not easy because of outdoor operations, complicated on-site plants and equipment operation coupled with workers involvement (Choudhry and Fang, 2008). Factors affecting labour productivity of workers on construction sites have been readily explored (Soekiman et al., 2011; Sweis et al., 2008; Lamka et al., 2014). Besides other trades, masons play an important role in the construction of buildings and concrete structures. Nonetheless, very little research has been conducted to explore factors affecting the competency of masons in the construction industry. Masonry activities such as mixing mortar, installing scaffold, cutting and laying block are labour intensive and need diverse skills in the masons to execute their tasks. Masonry is physically demanding (Spielholz et al., 2006) as masons and helpers have to stand for long episodes of time and lift heavy material (Boschman et al., 2011). Masons' work is substantially based on outdoor operations which expose masons to poor weather conditions which in turn reduces their productivity. Masonry contractors generally need to work in crews and they divide the work in different sections ( $\mathrm{Ng}$ and Tang, 2010). The contractors assign work tasks to masons depending upon the availability of crews and accessibility to the building areas. Even though the different crews of masons operate independently within their skill range, the contractors need to staff the crews properly to maximise productivity. Optimal assignment of tasks imparts a need for the contractors to prudently consider masons' skills and eradicate the factors that impede their performance. Florez and Castro-Lacouture (2014) proposed a sustainable approach to labour management in masonry construction, but their emphasis was on devising a decision support system for adequate allocation of crews in masonry construction rather than on exploring factors that affect masons' competency in construction. In addition, many of these studies $(\mathrm{Ng}$ and Tang, 2010; Florez and Castro-Lacouture, 2014) do not prioritise the relative importance of the factors related to masons. This work identifies and prioritises the factors related to the competency of masons on construction projects. 


\section{Literature review}

This section reviews the literature and describes the training system being enforced in the country for masons. It discloses the factors that are selected for this study.

Merriam Webster (2015) defines skill as the ability to use one's knowledge effectively and readily in execution or performance. An individual's overall abilities are made up of intellectual and physical skills (Choudhry, 2004). A skill is the learned ability to carry out a task with pre-determined results that one possesses. Skills can be divided into general and specific. For example, in the domain of work, some general skills would include time management, teamwork and leadership, whereas specific skills would be useful to perform a certain job.

Motivation is the result of the interaction of the individual and the situation (Choudhry, 2004). Motivation is a need-satisfying process. The most well-known theory of motivation is Maslow's (1954) 'hierarchy of needs'. These needs are physical, safety, affection, esteem, and self-development. Nonetheless, motivation is used to explain behaviour. It represents the reasons for people's actions, desires, and needs. Motivation can be defined as one's direction to behaviour or what causes a person to want to repeat behaviour and vice versa (Elliot, 2006). A motive is what prompts the person to act in a certain way or at least develop an inclination for specific behaviour (Pardee, 1990). For example, when someone takes meal to satisfy the need of hunger, or when a student does his/her work in school because he/she wants a good grade. Both show a similar connection between what we do and why we do it.

For the factors related to personality traits, 'the big five personality traits theory' is reviewed. The big five personality theory also known as 'the big five model' describes personality with the help of five fundamental traits which are 'openness to experience', 'conscientiousness', 'extroversion', 'agreeableness' and 'neuroticism' (OCEAN) (Cacioppo and Freberg, 2015). These personality traits represent the most important qualities that shape social landscape of individuals. Personality is a complex and varied and each person may display behaviours across several dimensions. Behaviour involves an interaction between a person's underlying personality and situational variables. The situation that a person finds himself or herself in plays a major role in how the person reacts. Nonetheless, in most cases, people offer responses that are consistent with their underlying personality traits.

Factors of skill and motivation are derived from literature review. The factor 'lack of education' is included as a factor of skills because without education up to a certain level, a mason cannot receive vocational training for skill development. A country lags behind other countries in trained manpower because of lack of education (Kazmi, 2007). 'Lack of formal training' is included as a factor of skills as it has an impact on skills. Vocational training improves the national competitiveness of workers (Wagner, 2005). Imoro and $\mathrm{Nti}$ (2009) reveal that vocationally trained masons are trusted by the contractors for being skilful. 'Lack of method statement' is identified as a factor of skills because a method statement provides standard operating procedure for doing the task in a specific manner. Not following a method statement poses hazards in the job site. 'Linguistic difference' is identified as a factor of skills because mason cannot execute the task correctly without having complete understanding of instructions. Linguistic barriers and cultural differences between foreign construction workers and field managers lead to the cause of faulty construction or inferior quality of work (Kim et al., 2015). Generally, masons belong to remote areas and speak their respective regional languages. There is a wide gap 
between the linguistic skills and education of masons and engineers as well as the supervisors that instruct them. 'Lack of experience' is identified as a factor affecting skills when skills enhance with the gain of experience. This is the reason that most contractors want to hire experienced masons (Memarian and Mitropoulos, 2011).

Workers consider expression of gratitude and praise by the supervisors as a reward, so 'lack of appreciation' is included as a factor affecting motivation. 'Verbal abuse' is a demotivating factor that $46 \%$ of women construction workers experience at work in India (Kumar, 2013). Owing to this, 'insult from supervisor' is selected as a factor affecting motivation. Rizvi (2012) reveals that 'job insecurity' has a negative effect on the satisfaction and motivation of the construction workers. 'Job insecurity' causes a lot of emotional, psychological, and motivational problems in workers, which justifies its inclusion as a factor affecting motivation. 'Lack of accommodation' is included as a factor affecting motivation. Jarkas and Radosavljevic (2013) describe motivational issues affecting the productivity of craftsmen in Kuwait and found 'payment delay' as one of the 10 most critical motivational factors.

'Resistance to change' is included as a factor of personality because people having low score on the scale of personality usually resist any change. 'Laziness' is selected as a factor of personality because it is the antithesis of the personality dimension of 'conscientiousness' (Ewen, 2010). 'Loneliness' is selected as a factor of personality traits because loneliness has negative correlation with the personality dimension of 'extraversion' (Atak, 2009). 'Short-temperedness' is selected as a factor of personality traits because lack of the personality dimension of 'agreeableness' causes an individual to be short-tempered (Griffin and Moorhead, 2009). Phipps and Prieto (2011) identify 'depression' as an element of the personality dimension of 'neuroticism', so depression is included as a factor of personality traits. The next section describes the formal and informal training system for masons in the developing country.

\subsection{The formal training system}

In Pakistan, the formal training system for skill development in masons is based on vocational education. Vocational training is provided both at secondary and post-secondary levels. Not all masons are involved in the system of apprenticeship. Vocational education schools provide both vocational certificates and degree programs. Masonry is one of the occupations for which a trade school education is required. The quality and effectiveness of vocational programs varies depending upon the secondary and postsecondary levels. Large sized and medium sized construction firms highly prefer recruiting workers from vocational training avenues (Fagbenle et al., 2012).

Many socio-economic factors influence the masons' tendency to seek formal training. A mason's income or his family income is one of the factors that play a decisive role in an individual's access to training. Many masons come from such family conditions that they are the sole bread earners for the household (Kazmi, 2007). This huge responsibility requires them to work simultaneously with training and they are generally not able to pay required attention in their training. Financial stress saps a worker's ability to devote full attention towards training and hence, their learning suffers. It is not easy for masons to receive formal training due to lack of enough formal training facilities in the country and financial constraints of masons. 


\subsection{The informal training system}

Owing to the shortage of vocational institutions, a lot of workers with huge potential are being trained on-site as helpers (Shagirds) under the guidance of their supervisors (called Ustads or skilled elders in the local language). Poor students generally abandon their studies after five years of education and develop their skills through an informal vocational training and join workforce. The informal system is also termed as 'training by traditional master craftsmen' or 'the traditional system' (Kakkar, 2014). The traditional system neither utilises latest work methods or latest technologies, nor does it modify in response to the latest research findings.

The technical knowledge of the training providers in the traditional system is often questionable as they are also trained by other non-technical elders in their own times. Most often, the trainers themselves learn the art the wrong way, and pass it over to their helpers down the line. Once the helper gets used to the traditional system, management can then make little difference. Even the formal training courses offered by management on site do not bring fruitful results because helpers are reluctant to relinquish the concepts delivered to them by their traditional trainers (Kakkar, 2014). Among engineers, skilled workers, semi-skilled workers and unskilled workers, the category that is $100 \%$ interested in seeking further training is of engineers, followed by skilled workers who have $69 \%$ interest in additional training, then semi-skilled workers who have $23 \%$ interest in extra training and lastly, unskilled workers who have $15 \%$ interest in more training (Huda, 2008). Huda (2008) revealed that the level of interest is directly proportional to level of skills and competence. Many workers prefer informal training system in comparison to formal training because it provides on-the-job training. In the formal system, workers need to attend vocational schools to complete their training. Not much research was conducted related to masons in the construction industry. This research is very important in the sense that perhaps, it is the pioneer study which investigates the effects of skills, motivation and personality traits on the competency of masons.

\section{Research method}

Research method of this study comprised a review of literature, face-to-face interviews, pilot study, followed by a questionnaire survey (Figure 1). Formula used by (Olomolaiye et al., 1987; Shash, 1993) was used to compute the relative importance index (RII) to rank the effect of each factor on the competency of masons. Mean of the RII of the factors belonging to each category yielded the RII of the respective categories.

Professionals of the construction industry were asked to approve the 15 factors identified through literature review that were included in the questionnaire. A professional engineer for this study is one who holds a bachelor degree in Civil Engineering has four years of experience and has passed an 8 hours Fundamentals of Engineering exam and an 8 hours Professional Engineers exam. There is no specific reason for selecting 8 professionals. Nine or ten were also possible. Nonetheless, when there were no more comments and saturation was felt, the writers thought eight professional are enough. These eight professionals were presented the preliminary list of factors in face-to-face interviews. Nonetheless, the selected professionals were having over ten years of experience as project managers, construction managers, and project engineers on construction projects and they had supervised masons (see Table 1) as well. 
It took 45 minutes to 1 hour to interview each professionals at their respective offices depending upon their available time slots. All professionals approved the identified factors as impactful on competency of masons, and suggested valuable changes in the language of the statements. For example, the factor 'no method statement' was changed to 'lack of method statement'. Another factor's statement was changed from 'fear of termination' to 'job insecurity'. The original statement 'salary not paid on time' was changed to 'delays in payment of salary'. The literature review and interviews steered to the development of the initial model of the questionnaire.

Figure 1 Research framework

Method

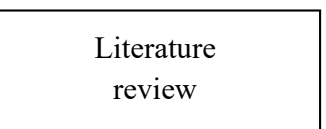

\
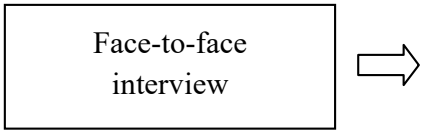

I
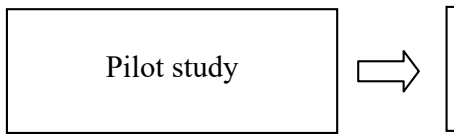

$\sqrt{2}$
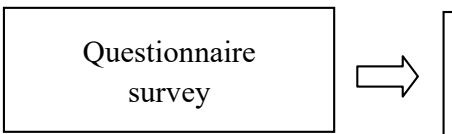
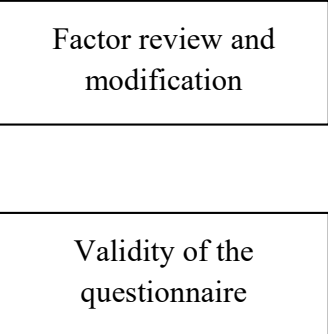

Purpose

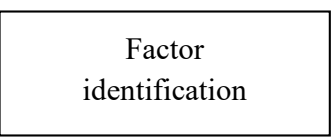

Prioritisation of factors
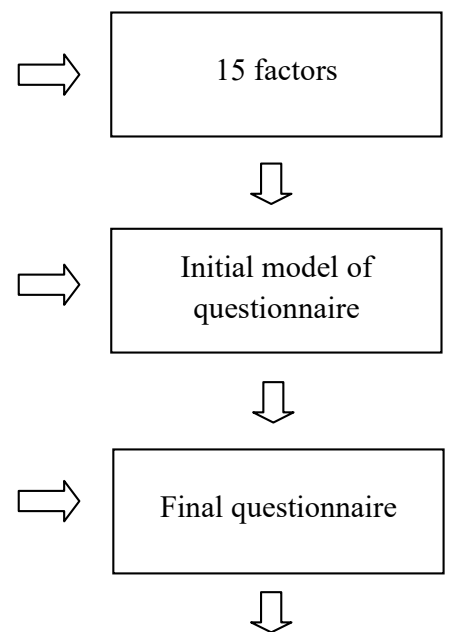

Ranked factors

Table 1

Professionals interviewed for factors

\begin{tabular}{lcc}
\hline Professional & Position & Experience (years) \\
\hline 1 & Project manager & 11 \\
2 & Project manager & 10 \\
3 & Project manager & 10 \\
4 & Project manager & 10 \\
5 & Project engineer & 13 \\
6 & Project engineer & 14 \\
7 & Construction manager & 12 \\
8 & Construction manager & 15 \\
\hline
\end{tabular}


A pilot study was conducted before sending questionnaires to the masons. The result of the pilot study was to evaluate the comprehensibility and validity of the questionnaire. Nine masons on the three largest construction projects were prompted to fill in the questionnaire. The largest three construction projects were selected for the pilot study of masons. Many masons do not understand the factors in English because of their lack of education. To enhance their comprehensibility, the factors were translated into Urdu (The country's national language). Six of the nine masons were able to read and understand the questionnaire whereas the other three required the researchers to read the factors for them. With duel language format, all masons were able to understand the factors and they assigned weights. There was no specific reason for selecting nine masons. The purpose was to validate the questionnaire. Eight or ten were also possible. Nonetheless, when no additional problems were identified and saturation was felt, the writers diverted their efforts in distributing the questionnaire. Final statements of the 15 factors were as follows:

Q1 lack of education

Q2 lack of formal training

Q3 lack of method statement

Q4 linguistic differences

Q5 lack of experience

Q6 lack of appreciation

Q7 insult from supervisor

Q8 job insecurity

Q9 lack of accommodation

Q10 delay in payment of salary

Q11 resistance to change

Q12 laziness

Q13 loneliness

Q14 short-temperedness

Q15 depression.

In line with the objective, the three categories of skills, motivation and personality traits were used to investigate their effect on the competency of masons. Nonetheless, this study was limited to the study of a total of 15 factors, five related to each category. The questionnaire had two parts. The first part was based on the masons' demographic information, including questions about their level of education, vocational certification, and experience in field work. The second part contained the 15 factors governing the competency of masons. Masons were asked to rate the 15 factors on the basis of their perceived negative impact on their competency on a five-point Likert Scale. The points 1, $2,3,4$, and 5 on the Likert scale stood for 'no negative impact', 'little negative impact', 'negative impact', 'strong negative impact', and 'extreme negative impact' respectively. 
The target of the questionnaire survey was masons working on different construction projects. To identify the population of masons, organisations that record data of the population of tradesmen in the construction industry were approached. Only the major organisation was the PBS (2014). Nonetheless, total population of masons in the industry was not available. Lack of record about the total population made it difficult to draw the sample size from the population. Formula for determining sample size when the total population is infinite was obtained from Shash and Abdul-Hadi (1993) as shown in equation (1).

$$
\mathrm{n}^{\prime}=\mathrm{S}^{2} / \mathrm{V}^{2}
$$

where

$\mathrm{n}^{\prime}$ sample size of an infinite population

$\mathrm{V}$ standard error whose value is 0.05 at $95 \%$ confidence level

$\mathrm{S}^{2}$ standard error variance of the population as given in equation (2) (Shash and Abdul-Hadi, 1993).

$$
\mathrm{S}^{2}=\mathrm{P}(1-\mathrm{P})
$$

$\mathrm{S}^{2}=$ maximum at the value of $\mathrm{P}=0.5$. The sample size is calculated as shown in equation (3).

$$
\mathrm{n}^{\prime}=\mathrm{S}^{2} / \mathrm{V}^{2}=(0.5)^{2} /(0.05)^{2}=100
$$

The researchers visited the construction projects to collect data from 114 masons. There was no non-response case when masons were approached after visiting construction projects. Cooperation of project managers and site engineers were sought to contact masons. It took over four months to gather data.

Formula for the RII was used to rank the impact of each factor on the competency of masons. The formula for the RII (Chan and Kumaraswamy, 1997, Enshassi et al., 2008) is:

$$
\mathrm{RII}=\sum \mathrm{w} /(\mathrm{A} \times \mathrm{N})
$$

where $\mathrm{w}=$ weight assigned by each respondent in a range from 1 to 5 , where 1 infers no negative impact, and 5 suggests extremely negative impact; $\mathrm{A}=$ highest weight, e.g., 5; $\mathrm{N}=$ total number of respondents.

After data collection, the efforts were diverted towards analysis. RII for each category was determined by taking the mean of the RIIs of the constituent factors.

\section{$4 \quad$ Analysis and results}

Responses obtained from the masons were entered in a spreadsheet for analysis. $57 \%$ of the masons were illiterate, $33 \%$ had received five years of primary education, and $7 \%$ were having 8 years of education, whereas only 3\% masons had received ten years of education (see Table 2). Additionally, $86 \%$ of the masons were trained via the informal apprenticeship system, and $14 \%$ had received formal vocational training. Furthermore, 
$68 \%$ of the masons had received vocational certification, whereas $32 \%$ did not have the vocational certification.

Table 2 Demographic information of the respondents

\begin{tabular}{llc}
\hline S. no. & Description & Percentage of mason \\
\hline 1 & Education & \\
& Illiterate & $57 \%$ \\
& Five years primary education & $33 \%$ \\
& Eight years middle education & $7 \%$ \\
& Ten years secondry school education & $3 \%$ \\
& Training & \\
& Informal apprenticeship & $86 \%$ \\
& Formal (vocational) & $14 \%$ \\
3 & Certification & \\
& Vocational certification & $68 \%$ \\
& No certification & $32 \%$ \\
\hline
\end{tabular}

Table 3 displays the RII and ranks of factors. 'Resistance to change' was found to have the maximum impact on the competency of masons as it was ranked at the top with $(\mathrm{RII}=0.448)$. 'Lack of appreciation' was ranked second with $(\mathrm{RII}=0.440)$. The factor 'lack of formal training' was ranked third with $(\mathrm{RII}=0.436)$. The factor 'lack of accommodation' was ranked 4th with $(\mathrm{RII}=0.412)$. 'Lack of method statement' was ranked 5th with RII of 0.406. 'Delay in payment of salary' was ranked 6th with RII of 0.394 . The readers are asked to see Table 3 for ranking rest of the factors. 'Short-temperedness' was ranked 15th with $(\mathrm{RII}=0.236)$, and was thus the factor with minimal impact on the masons' competency among all 15 factors.

Table 3 Factors and their impact on competency of masons

\begin{tabular}{lccc}
\hline Factor & RII & Rank & Category \\
\hline Resistance to change & 0.448 & 1 & Personality traits \\
Lack of appreciation & 0.440 & 2 & Motivation \\
Lack of formal training & 0.436 & 3 & Skill \\
Lack of accommodation & 0.412 & 4 & Motivation \\
Lack of method statement & 0.406 & 5 & Skill \\
Delay in payment of salary & 0.394 & 6 & Motivation \\
Loneliness & 0.362 & 7 & Personality traits \\
Lack of education & 0.356 & 8 & Skill \\
Insult from supervisor & 0.350 & 9 & Motivation \\
Linguistic differences & 0.344 & 10 & Skill \\
Job insecurity & 0.312 & 11 & Motivation \\
Lack of experience & 0.298 & 12 & Skill \\
Depression & 0.292 & 13 & Personality traits \\
Laziness & 0.254 & 14 & Personality traits \\
Short-temperedness & 0.236 & 15 & Personality traits \\
\hline
\end{tabular}


Table 4 indicates the RII of each category obtained from the mean of RII of their constituent factors. Category of 'motivation' had the highest RII, followed by the category of 'skill', and the category of 'personality traits' had the lowest RII. RII of 'motivation' and 'skill' differed by 0.0136 . RII of 'skill' and 'personality traits' differed by 0.0496 . RII of 'motivation' and 'personality traits' differed by 0.0632 .

Table 4 RII of categories

\begin{tabular}{lc}
\hline Category & RII \\
\hline Motivation & 0.3816 \\
Skill & 0.3680 \\
Personality traits & 0.3184 \\
\hline
\end{tabular}

\section{Discussions}

This section discussed the results mainly in the sequence as shown in Table 3 and Table 4. The factor 'resistance to change' was ranked at the top in terms of its impact on the competency of masons. 'Lack of appreciation' was ranked second and 'lack of formal training' was ranked third. Because of low of education and training, masons often resist changes and are reluctant to follow new methods and technology. Nonetheless, construction projects are susceptible to changes in plan, methodology, and scope. Rarely, a construction project is completed without any change in the original plan. Masons need to adjust to these changes frequently because they are involved in the execution of a variety of construction activities. New and innovative methods of construction are surfacing particularly with the advancement of technology. Having developed their expertise in the traditional methods of construction, construction workers intend to resist in adapting themselves to such changes. Researchers assert that managers need to gain the approval of employees in order to enhance their participation in the change (Cheng et al., 2006).

Lack of appreciation from managers deters workers from getting an objective idea of what is expected and accordingly, they cannot improve their competency. Appreciating and encouraging workers is an intrinsic reward that construction managers need to offer. Construction managers cannot eliminate negative behaviours and foster positive behaviours without appreciating the workers for their good work (Wei and Yazdanifard, 2014).

Eighty six (86\%) of the masons in this study developed their skills through the informal apprenticeship system. Training optimises a worker's tendency to perform better in the field. The knowledge and practice gained during training benefits workers while performing in the field. This has serious repercussions on the performance of construction workers. Roessger (2011) argues that training of construction tradesmen instils skills in them and training need to be used as a way of overcoming barriers to their performance. One of the main advantages of providing construction workers with training is enhancement of their focus on the job-related skills. Training clarifies job tracks to workers, and equips them with skills. Training helps construction managers develop the skills of workers in a traditionally sustainable industry. Training of construction workers provides a unique platform for integrating academic skills into the occupational training. 
Lack of training particularly affects the performance of new workers on construction project. Proper vocational training enhances competitiveness of workers (Wagner, 2005).

Factor 'lack of accommodation' is ranked at 4th place. Many construction companies accommodate too many workers in one room to minimise the cost of rent. Cabin-sharing impairs workers' quality of sleep and recovery from the fatigue related to work (Parkes, 2010).

Method statement provides workers with detailed information about the technical specifications and construction procedures of activities. Lack of method statement places the entire responsibility on the workers. Rules and procedures are important components that workers need to follow (Choudhry and Fang, 2008). Method statements are particularly significant because standards procedures provide workers to perform safely. Having a good method statement, workers feel safe and they are more productive, thus showing their competency.

Factor 'delay in payment of salary' was ranked at the 6th place. Delay in payment to workers causes worry to masons. Lack of a well-designed compensation scheme for the productivity shown by the construction workers, is a cause of stress, which in turn has negative effects on their competency (Oyewobi et al., 2011).

Many construction workers feel loneliness because of being distant from their families. Construction is a labour-intensive job and often requires workers to be present on the site all the time. This sometimes induces a sense of dissatisfaction and loneliness in the workers.

This study found that construction workers were less educated. The construction industry employs workers with little education $(90 \%$ were having up to five years of education) and many of whom belong to the poor sections of the society. Nonetheless, multiplying figures and measuring lengths is part of a mason's job. Masons require basic knowledge of math to perform well. Kazmi (2007) found insufficient role of vocational schools in the training of workforce. None of the masons had a higher level of education than the secondary school certificate (SSC). In Nigeria, $58.1 \%$ of the artisans in the construction industry were found to be totally illiterate, with $28.6 \%$ artisans having primary education, and only $6.7 \%$ are educated till the SSC and junior school certificate (Wahab, 2010).

Insulting workers is common on many construction projects. Construction workers generally belong to the poor and unprivileged segments of the society, and their supervisors do not hesitate to insult them. Workers on construction projects are verbally abused, held responsible for inaccuracy of work and delays and dealt with impolitely. Construction managers and supervisors are often not conscious of the consequences of even the smallest of their actions on the motivation, attitude, and performance of the workers. Insult from the supervisor causes demotivation in the workers which in turn lowers their competency. Constant insult from a supervisor cultivates a feeling in the workers that no amount of hard work is to suffice, so they stop making effort to satisfy their supervisors.

The factor 'linguistic differences' was ranked at the 10th place. Masons are to be competent in the language in which they communicate with each other and with their manager. Linguistic differences particularly affect the competency of the migrant construction workers. This includes both workers that migrate from one area of the country to another because of difference of regional languages, and workers who migrate from Afghanistan and other countries for work having different national languages. 
Job insecurity causes psychological and emotional problems in masons and reduces their productivity. Job insecurity is one of the main factors that induces stress in the workers, and negatively impacts their competency. Only 20\% management on construction projects provides job security to workers (Khan and Ajmal, 2015).

The importance of experience is evident from the fact that reductions in construction employment tend to fall in a recession as employers try to maintain their experienced and skilled workers as long as it is viable to do so. Tabassi and Bakar (2009) found lack of experience of workers is a causal factor for low quality on construction projects. Research indicates that lack of experience of workers reduces profitability by causing delays in construction (Koushki et al., 2005).

The factor 'depression' was ranked at the 13th place. Masons generally work overtime on construction projects and long working hours has become a norm in the construction industry. The labour-intensiveness and risky working environment of construction induces depression in workers which in turn declines their competency (Wong et al., 2010).

Laziness is one of the main inhibitor of productivity of construction masons. Many construction workers waste their time in unproductive activities like arguing and talking with co-workers.

The factor which is ranked at the last is short-temperedness in this study. Short-temperedness of the workers increases their tendency to engage in group conflicts that cause delays on construction sites (Assaf and Al-Hejji, 2006). Investigators found that most workers in the construction industry of Nigeria get angry and experience headache as a result of the problems encountered at work (Oyewobi et al., 2011).

Overall, this work identified and prioritised the factors related to the competency of masons on construction projects. Construction managers primarily control all factors related to motivation explored in this research. Construction managers can assist the masons in the personality traits issues. Construction managers are responsible to improve the competency of masons by setting policies and improving their best practices. Construction managers need to foster a culture in which masons can adjust to changes and they be appreciated irrespective of their financial status or level of education. Only if construction managers encourage their supervisors to assist masons to adopt new changes and praise the workers for their good performance, they would be able to eradicate the first and second most important factors (resistance to change, lack of appreciation) in the competency of masons. The results obtained for personality traits were found to be mostly on the extreme as one of its factors was ranked first in terms of RII, and three came at the 13th, 14th, and 15th positions (see Table 3). This indicates a vast disparity in the impact of the five personality traits on the competency of masons in construction. A noticeable finding of this research is that the category of 'motivation' has the maximum impact on the competency of masons (see Table 4), with the category of 'skill' being in the middle, and the category of 'personality traits' in the last which indicates its least impact on masons' competency. Nonetheless, when the impact of individual factors on masons' competency is analysed (see Table 3), factors related to each category are randomly distributed. This indicates that the construction managers need to rely on the ranking of individual factors more than the ranking of the three categories while prioritising their measures and strategies to improve the competency of masons. 


\section{Conclusions}

This work was designed to identify and prioritise the factors related to the competency of masons in construction environments of a developing country. Of the three categories skill, motivation, and personality traits; motivation was found to have the highest impact on masons' competency, followed by skill, and in the last, personality traits. Top three factors related to the categories of personality traits, motivation, and skill when arranged in order of their impact on the competency of masons include resistance to change, lack of appreciation, and lack of formal training. The findings on the impact of skill, motivation, and personality traits on the competency of masons serve as a guideline for the construction managers in their endeavours to improve workers' competency. This research provides the construction managers realise which factors to target to bring quick and radical improvements in the competency of masons.

While skill, motivation, and personality traits are identified as the core features of workers' competency, perhaps no attempt was made in the past to check their relative impact on the competency of masons. This research has filled this gap in the existing body of literature by developing 15 factors and ranking them. Nonetheless, the study took into account very basic facts and it had not investigated the technical competency of construction workers. Additionally, the respondents of this research were all masons; therefore, the findings cannot be generalised for all construction tradesmen though the factors of competency are commonly experienced by all construction tradesmen.

\section{References}

Assaf, S.A. and Al-Hejji, S. (2006) 'Causes of delay in large construction projects', International Journal of Project Management, Vol. 24, No. 4, pp.349-357.

Atak, H. (2009) 'Big Five traits and loneliness among Turkish emerging adults', International Scholarly and Scientific Research and Innovation, Vol. 3, No. 7, pp.771-775.

Boschman, J.S., van der Molen, H.F., Sluiter, J.K. and Frings-Dresen, M.H.W. (2011) 'Occupational demands and health effects for bricklayers and construction supervisors: a systematic review', American Journal of Industrial Medicine, Vol. 54, No. 1, pp.55-77.

Cacioppo, J. and Freberg, L. (2015) Discovering Psychology: The Science of Mind, 2nd ed., Cengage Learning, Boston.

Chan, D.W.M. and Kumaraswamy, M.H. (1997) 'A comparative study of causes of time overruns in Hong Kong construction projects', International Journal of Project Management, Vol. 15, No. 1, pp.55-63.

Cheng, M.I., Dainty, A. and Moore, D. (2006) 'Implementing a new performance management system within a project-based organization: a case study', International Journal of Productivity and Performance Management, Vol. 56, No. 1, pp.60-75.

Choudhry, R.M. (2004) 'Incentives, ability and various aspects of motivation', Science, Technology and Development, Vol. 23, No. 4, pp.1-6.

Choudhry, R.M. and Fang, D.P. (2008) 'Why operatives engage in unsafe work behavior: investigating factors on construction sites', Safety Science, Vol. 46, No. 4, pp.566-584.

Dubois, D.D., Rothwell, W.J., Stern, D.J.K. and Kemp, L.K. (2004) Competency-Based Human Resource Management, Davies-Black Publishing, California.

Elliot, A.J. (2006) 'The hierarchical model of approach-avoidance motivation', Motivation and Emotion, Vol. 30, No. 2, pp.111-116. 
Enshassi, A., Choudhry, R.M., Mayer, P.E. and Shoman, Y. (2008) 'Safety performance of subcontractors in the Palestinian construction industry', Journal of Construction in Developing Countries, Vol. 13, No. 1, pp.51-62.

Ewen, R. (2010) An Introduction to Theories of Personality, 7th ed., Psychology Press, New York.

Fagbenle, O.I., Lawal, P.O. and Omuh, I.O. (2012) 'The influence of training on bricklayers' productivity in Nigeria', International Journal of Management Sciences and Business Research, Vol. 1, No. 7, pp.1-13.

Florez, L. and Castro-Lacouture, D. (2014) 'Labor management in masonry construction: a sustainable approach', Proceedings: The 31st International Symposium on Automation and Robotics in Construction and Mining (ISARC), Theme: Automation, Construction and Environment, 9-11 July, pp.529-536, Sydney, Australia.

Griffin, R. and Moorhead, G. (2009) Organizational Behavior: Managing People and Organizations, 9th ed., South-Western College Pub., Cincinnati, $\mathrm{OH}$.

Huda, S.M.K. (2008) 'Assessment of Deming's philosophy with respect to its link to the current scenario in the Pakistani construction industry', Proceedings: 1st International Conference on Construction in Developing Countries (ICCIDC-I), Advancing and Integrating Construction Education, Research and Practice, 4-5August, Karachi, pp.247-259.

Imoro, B. and Nti, K.O. (2009) 'Sustainable vocational skills development for poverty reduction in Northern Ghana', Journal of Sustainable Development in Africa, Vol. 10, No. 4, pp.250-267.

Jarkas, A.M. and Radosavljevic, M. (2013) 'Motivational factors impacting the productivity of construction master craftsmen in Kuwait', Journal of Management in Engineering, Vol. 29, No. 4, pp.446-454.

Kakkar, A. (2014) 'Training construction workers for sustainable environment', International Journal of Environmental Research and Development, Vol. 4, No. 1, pp.21-26.

Kazmi, S.W. (2007) 'Vocational education and skills development: a case of Pakistan', SAARC Journal of Human Resource Development, Vol. 3, No. 8, pp.105-117.

Khan, A.A. and Ajmal, S. (2015) 'Role of management in motivating labor to improve labor productivity', Journal of Advanced Management Science, Vol. 3, No. 3, pp.179-185.

Kim, S., Kim, J., Cho, H., Shin, Y. and Kim, G. (2015) 'Finding cultural differences and motivation factors of foreign construction workers', Journal of Building Construction and Planning Research, Vol. 3, No. 2, pp.35-46.

Koushki, P.A., Al-Rashid, K. and Kartam, N. (2005) 'Delays and cost increases in the construction of private residential projects in Kuwait', Construction Management and Economics, Vol. 23, No. 3, pp.285-294.

Kumar, B.R. (2013) 'Gender discrimination among construction workers with reference to Vijayawada', Journal of Sociology and Social Work, Vol. 1, No. 1, pp.42-53.

Lamka, A.H.V., Masu, S.M., Wanyona, G., Dianga, S. and Gwaya, A.O. (2014) 'Factors influencing effective productivity on construction sites in Nairobi County', International Journal of Soft Computing and Engineering, Vol. 4, No. 5, pp.24-30.

Maslow, A. (1954) Motivation and Personality, Harper \& Row, New York.

Memarian, B. and Mitropoulos, P. (2011)'Work factors affecting task demands of masonry work', Proceedings: 47th ASC Annual International Conference, Associated Schools of Construction, 6-9April, Nebraska.

Memon, A.H., Rahman, I.A., Abdullah, M.R., Azis, A.A.A. and Rakyat, M.A. (2014) 'Factors affecting construction cost performance in project management projects: case of MARA large projects', International Journal of Civil Engineering and Built Environment, Vol. 1, No. 1, pp.30-35.

Merriam Webster (2015) Meaning of Skill [online] http://www.merriamwebster.com/dictionary/Skill (accessed 6 August 2015).

Ng, S.T. and Tang, Z. (2010) 'Labour-intensive construction sub-contractors: their critical success factors', International Journal of Project Management, Vol. 28, No. 7, pp.732-740. 
Olomolaiye, P.O., Wahab, K.A. and Price, A.D.F. (1987) 'Problems influencing craftsmen's productivity in Nigeria', Building and Environment, Vol. 22, No. 4, pp.317-323.

Oyewobi, L.O., Adamu, A.D., Ganiyu, B.O. and Odelade, O.M. (2011) 'Impact of stress management on the productivity of workers on Nigerian construction sites', Built Environment Journal, Vol. 8, No. 2, pp.1-8.

Pakistan Bureau of Statistics (PBS) (2014) Labor Force Statistics, Pakistan Bureau of Statistics, Government of Pakistan, Islamabad.

Pardee, R.L. (1990) Motivation Theories of Maslow, Herzberg, McGregor \& McClelland: A Literature Review of Selected Theories Dealing with Job Satisfaction and Motivation, ERIC Document ED316767, February.

Parkes, K.R. (2010) Offshore Working Time in Relation to Performance, Health and Safety: A Review of Current Practice and Evidence, Research Report 772, Health and Safety Executive, Oxford.

Phipps, S.T.A. and Prieto, L.C. (2011) 'The influence of personality factors on transformational leadership: exploring the moderating role of political skill', International Journal of Leadership Studies, Vol. 6, No. 3, pp.430-447.

Rizvi, L. (2012) 'Examining the impact of job security, organizational climate and engagement on motivation level of employees at IMC PVT LTD', European Journal of Business and Management, Vol. 4, No. 9, pp.27-35.

Roessger, K.M. (2011) 'Using building and construction trades training to empower African American adult learners in a changing urban economy', Proceeding: Midwest Research-toPractice Conference in Adult, Continuing, Community and Extension Education, Lindenwood University, 21-23 September, pp.1-6, Saint Charles.

Shash, A. and Abdul-Hadi, N. (1993) 'The effect of contractor size on mark-up size decision in Saudi Arabia', Construction Management and Economics, Vol. 11, No. 6, pp.421-429.

Shash, A.A. (1993) 'Factors considered in tendering decisions by top UK contractors', Construction Management and Economics, Vol. 11, No. 2, pp.111-118.

Soekiman, A., Pribadi, K.S., Soemardi, B.W. and Wirahadikusumah, R.D. (2011) 'Factors relating to labor productivity affecting the project schedule performance in Indonesia', Proceedings of the Twelfth East Asia-Pacific Conference on Structural Engineering and Construction, pp.865-873, Elsevier Ltd., Kowloon.

Spielholz, P., Davis, G. and Griffith, J. (2006) 'Physical risk factors and controls for musculoskeletal disorders in construction trades', Journal of Construction Engineering and Management, Vol. 132, No. 10, pp.1059-1068.

Sweis, G.J., Sweis, R.J., Hammad, A.A.A. and Thomas, H.R. (2008) 'Factors affecting baseline productivity in masonry construction: a comparative study in the US, UK and Jordan', Architectural Science Review, Vol. 51, No. 2, pp.146-152.

Tabassi, A.A. and Bakar, A.H.A. (2009) 'Training, motivation, and performance: the case of human resource management in construction projects in Mashhad, Iran', International Journal of Project Management, Vol. 27, No. 5, pp.471-480.

Wagner, K. (2005) 'Productivity and skills in industry and services - a British-German comparison', The Pakistan Development Review, Vol. 44, No. 4, pp.411-438.

Wahab, A.B. (2010) 'Stress management among artisans in construction industry in Nigeria', Global Journal of Researches in Engineering, Vol. 10, No. 1, pp.93-103.

Wei, L.T. and Yazdanifard, R. (2014) 'The impact of positive reinforcement on employees' performance in organizations', American Journal of Industrial and Business Management, Vol. 4, No. 1, pp.9-12.

Wong, J., Teo, M. and Fiona, Y.K. (2010) 'Cultural determinants of stress in the construction industry', Proceedings of 2010 International Conference on Construction \& Real Estate Management, China Architecture \& Building Press, Brisbane, pp.44-49. 